\title{
Research and conservation in Marina el-Alamein in 2016 (Polish-Egyptian Conservation Mission)
}

\author{
Rafał Czerner,' Grażyna Bąkowska-Czerner, \\ Wiesław Grzegorek ${ }^{3}$ and Piotr Zambrzycki ${ }^{4}$ \\ ${ }^{1}$ Wrocław University of Science and Technology, ${ }^{2}$ Jagiellonian University, \\ ${ }^{3}$ independent, PCMA associate, ${ }^{4}$ InterAcademy Institute of Conservation \\ and Restoration of Works of Art
}

\begin{abstract}
Activities undertaken by the Polish-Egyptian Conservation Mission to Marina el-Alamein in 2016 included research and conservation in the public district of the ancient town as well as in private houses. Work focused foremost on research, conservation and exhibition of monuments in the central town square, especially the remains of a peristyle adjacent from the east, and the southern portico of the square itself. Research and conservation continued also in the area north of the central square, concentrating on the remains of public baths dating from the Hellenistic period and, on the south, on the remnants of Roman baths in use from the 2 nd to the 3 rd century AD. Maintenance conservation was carried out in private houses, in both baths complexes and in the eastern and southern area of the central square.
\end{abstract}

Keywords: Marina el-Alamein, town center, main square, northern and southern baths, houses, research, preservation, conservation

Announced by the Ministry of Antiquities, the imminent opening of the archaeological excavation site in Marina el-Alamein to visitors ${ }^{1}$ demanded that the Polish-Egyptian Conservation Mission from the Polish Centre of Mediterranean Archaeology University of Warsaw, cooperating with the Wroctaw University of Science and Technology, undertake its work in 2016 first of all in areas foreseen to be a part of the visitors' itinerary.
Conservation and preservation priorities for the current season were also largely determined by the visible effects of exceptionally unfavorable weather conditions in the autumn and winter of 2015/2016.

The season was short, but effective. In large measure, this is owed to the efficient organization of the mission's work by our Egyptian hosts and to their help with all the activities.

1 During his visit to the site on 28 May 2016 the Minister of Antiquities of Egypt, Dr. Khaled El-Enany, reiterated that the opening of the site to tourism was to be expected soon. 


\section{MAIN AREAS OF ACTIVITIES}

As part of preparations for the opening of the historic complex to visitors, the management of the site outlined a short guided route which is to be made available in the first stage. Currently, it includes several structures in the necropolis. The center of the ancient town, particularly its main square tentatively identified as the forum or agora (Daszewski et al. 2005: 86-92; Daszewski2011:423), and the surrounding building remains form an architecturally distinctive historic complex that is located nearby and can easily be included in the guided tour [Fig. 1]. The prime focus of the mission was on this area, the work being a continuation of systematic conservation and research work done in the past. In 2016, this included mainly work in the square itself, in the peristyle adjoining its eastern side and in two complexes of public bath remains: the Roman one situated to the south of the square and the Hellenistic one to the north.
The exploration and conservation of the southern bath complex started in 2007 (Medeksza et al. 2010: 88-91), while work in the northern complex was first undertaken in the 2014 season (Czerner et al. 2016b: 167-171, 173ff.). Research and preservation were continued currently in both structures. More extensive research and conservation work were undertaken in the forum, in its eastern peristyle in particular, this constituting the main task of the season.

Standard monitoring of the state of preservation of historic monuments on site in 2016 revealed many structures in need of additional conservation and protection from further damage. Such maintenance work has been carried out at the site by the mission for many years. Damage processes, intensified due to particularly unfavorable weather conditions in the autumn/winter period, required this activity to be more extensive in the current season. Maintenance conservation and

Team

Dates of work: 3-30 May 2016

Director: Prof. Rafał Czerner, architect (Wrocław University of Science and Technology)

$S C A$ representatives: Nama Sanad Yakoub (Marina Site Director), Haitham Abd Allatief Ali Abd Allal (SCA inspector)

Archaeologist: Dr. Grażyna Bąkowska-Czerner (Jagiellonian University in Kraków)

Archaeologist/glass expert: Renata Kucharczyk (PCMA UW)

Architects: Wiesław Grzegorek (freelance, PCMA associate), Sara Arbter (undergraduate student, Wrocław University of Science and Technology)

Stone and sculpture conservator: Piotr Zambrzycki (InterAcademy Institute of Conservation and Restoration of Works of Art)

\section{Acknowledgments}

The assistance throughout the season of General Director of the Marina el-Alamein site, Mrs. Nama Sanad Yakoub, and SCA Inspector, Mr. Haitham Abd Allatief Ali Abd Allal, is gratefully appreciated. 


\section{EGYPT}

preservation were carried out mainly in the area of the town center: the forum, its eastern peristyle and both bath complexes, as well as in houses H9, H9a, H10a and
$\mathrm{H} 21 \mathrm{~N}$, and also, to a limited extent, in house $\mathrm{H} 1$ and in the necropolis. Object conservation was also carried out in the 2016 season.

\section{NORTHERN HELLENISTIC BATHS}

The Hellenistic baths located north of the central square were discovered by Egyptian archaeologists in 1987 (Daszewski 1991: 16; 1995: 18, Fig. 4; 2011: 429; Fournet et al. 2013: 326). At that time, the functional elements of their main body were identified. Studies undertaken during the conservation and research works carried out by the Polish-Egyptian
Conservation Mission in the 2014 and 2015 seasons confirmed the functions of the main rooms and the existence of several phases of functioning (Czerner et al. 2016b: 167-182) [Fig. 2]. It was typical of this kind of buildings in Egypt at the beginning of Roman domination (Breccia 1923; Yegül 1992: 24, 29; Daszewski 1995: 18-19, Figs 3, 4) and housed a set

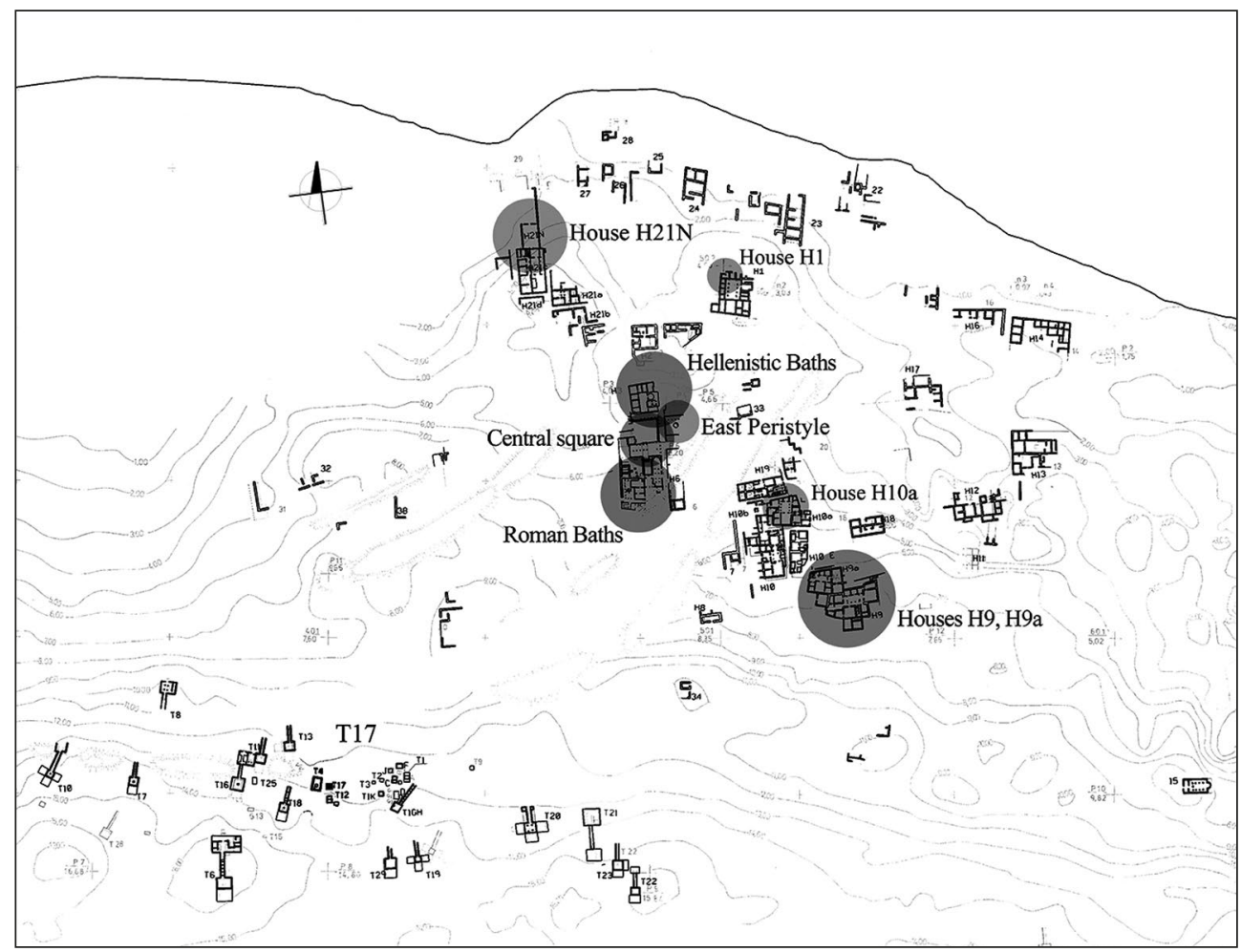

Fig. 1. Marina el-Alamein site plan: circles mark areas of work undertaken in the 2016 season (PCMA Marina el-Alamein Conservation Mission) 
of rooms that were essential in Hellenistic baths (corresponding to the second model according to Monika Trümper [2009: $149,152-153])$. Situated in the center of the eastern area of the baths, the main rooms and facilities included a tholos $(1$ in Fig. 2) with nine hip-bathtubs and a larger one, a possible immersion bathtub, by the wall and, neighboring to the west, a small room (2) housing an immersion tub. In the north section, a vast water reservoir was located on a raised superstructure (3) in the northeastern corner of the building, and a heating appliance was set

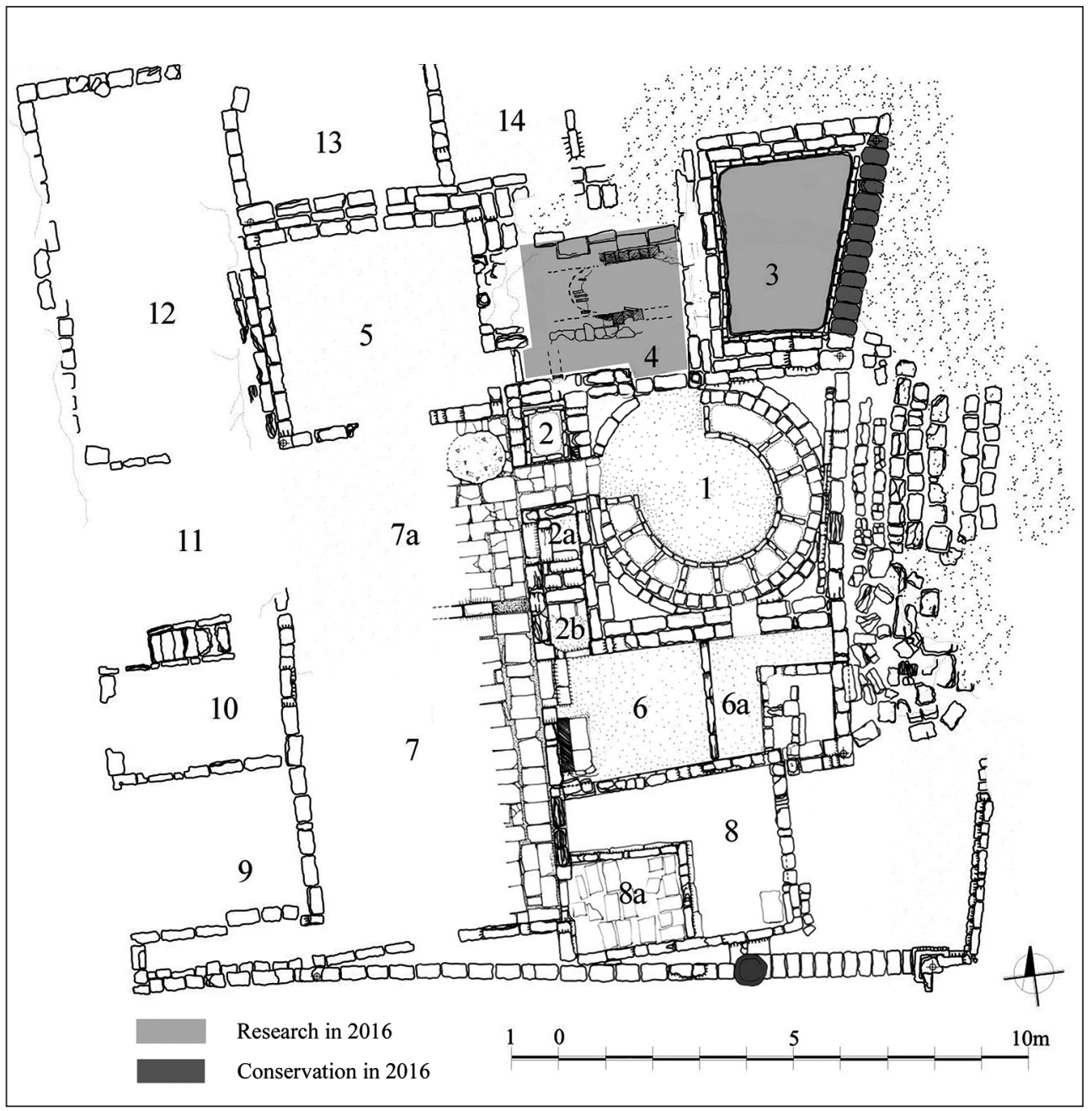

Fig. 2. Baths located north of the central square at Marina el-Alamein; plan showing areas of activities in 2016 (PCMA Marina el-Alamein Conservation Mission/drawing R. Czerner, M. Grzegorek, M. Krawczyk-Szczerbinska) 
in a room (4) adjacent to the west. In the 2014 and 2015 seasons, research in the rooms (6-8) located south of the tholos was also carried out and at least two phases of functioning were confirmed. However, the function of these chambers remains yet to be explained.

In the current season, research was completed on the water reservoir (3) [Fig. 2]; in particular its bottom was examined and it was confirmed there is no outlet in it. As part of conservation work, in order to protect the eastern edge of the brick casing of the reservoir, one layer of stone blocks was added to the top of the east wall of the room housing it.

Exploration of the neighboring room (4) [see Fig. 2] revealed the upper parts of a furnace built of red bricks bonded in clay mortar. Walls made of vertically placed limestone slabs were built adjacent to the brick furnace walls on the north and south, sectioning out the middle part of the chamber with the heating appliance. The furnace was operated through an opening on the northern side. The inside brick walls supported a barrel vault made of brick halves. The vault has collapsed to a large extent. Exploration of the deeper parts of the furnace was not undertaken at this time and the relic was protected until further work can be carried out.

\section{ARCHAEOLOGICAL RESEARCH}

In the northern baths, part of room 4 was cleaned as well as all of unit 3, which constituted a water reservoir [see Fig. 2]. Room 4, measuring $3.87 \mathrm{~m}$ by $3.10 \mathrm{~m}$, has walls about $0.40 \mathrm{~m}$ wide. A door opening, $0.70 \mathrm{~m}$ wide, in the west wall by the southern corner of the room and leading to room 5 , turned out to have been blocked at a later date. A door (1.03-1.10 m wide) in the south wall, leading to the tholos, is also closed with big stone blocks laid to a height of $0.65 \mathrm{~m}$. A narrow corridorpassage from the tholos to room 5, separated from the chamber space in the southern part of the room in a later phase, was $0.90 \mathrm{~m}$ wide. The big stone blocks in the upper layers of the fill must be tumble from the south wall. They lay on a layer of pure sand about $0.20 \mathrm{~m}$ thick. Fragments of two amphorae, as well as of a frying pan and pieces of kitchenware were discovered under this layer. The pottery came from a later phase of use.

The northern part of the room was occupied by a furnace. Big stone slabs $(0.60 \times 0.36 \times 0.10 \mathrm{~m})$ were found above the furnace, coming probably from the collapsed south wall of the structure. A corroded coin and several fragments of ceramics were found in the fill. The vault between the brick walls of the furnace body spanned approximately $1.05 \mathrm{~m}$. Work here will be continued.

Unit 3 of irregular plan housed a water tank. The walls were $0.40 \mathrm{~m}$ wide on the south and west and $0.60 \mathrm{~m}$ wide on the north and east. The tank measured $4.04 / 3.52 \mathrm{~m}$ by $3.10 / 1.70 \mathrm{~m}$ and was about $0.90-1.20 \mathrm{~m}$ deep, encased in bricks and lined with waterproof mortar. A doorway, $0.70 \mathrm{~m}$ wide, was noted $0.40 \mathrm{~m}$ above the bottom of the tank in its south wall. In the later phase, stone blocks divided the tank into two. There were no archaeological finds, the tank having been cleaned during earlier research in the 1980 s.

[GB-C] 


\section{SOUTHERN ROMAN BATHS}

The small baths from the Roman period located south of the central square are typical balnea (see Nielsen 1990: 3) and, considering the layout of the main rooms, they follow a row-type organization (see Krenckner et al. 1929: Fig. 234-240; Nielsen 1990: 87). Remains of the baths were excavated for the PCMA by Wiktor Andrzej Daszewski in 1987 (Daszewski
1995: 19-20) and again in 2005 (Daszewski et al. 2007: 79-82). Research was continued in 2005 (Daszewski et al. 2007: 79-83), 2006 and 2007 by the Polish mission and by Egyptian archaeologists contracted by the American ARCE/EAP Marina el-Alamein Site Presentation project. The Conservation Mission has continued conservation and

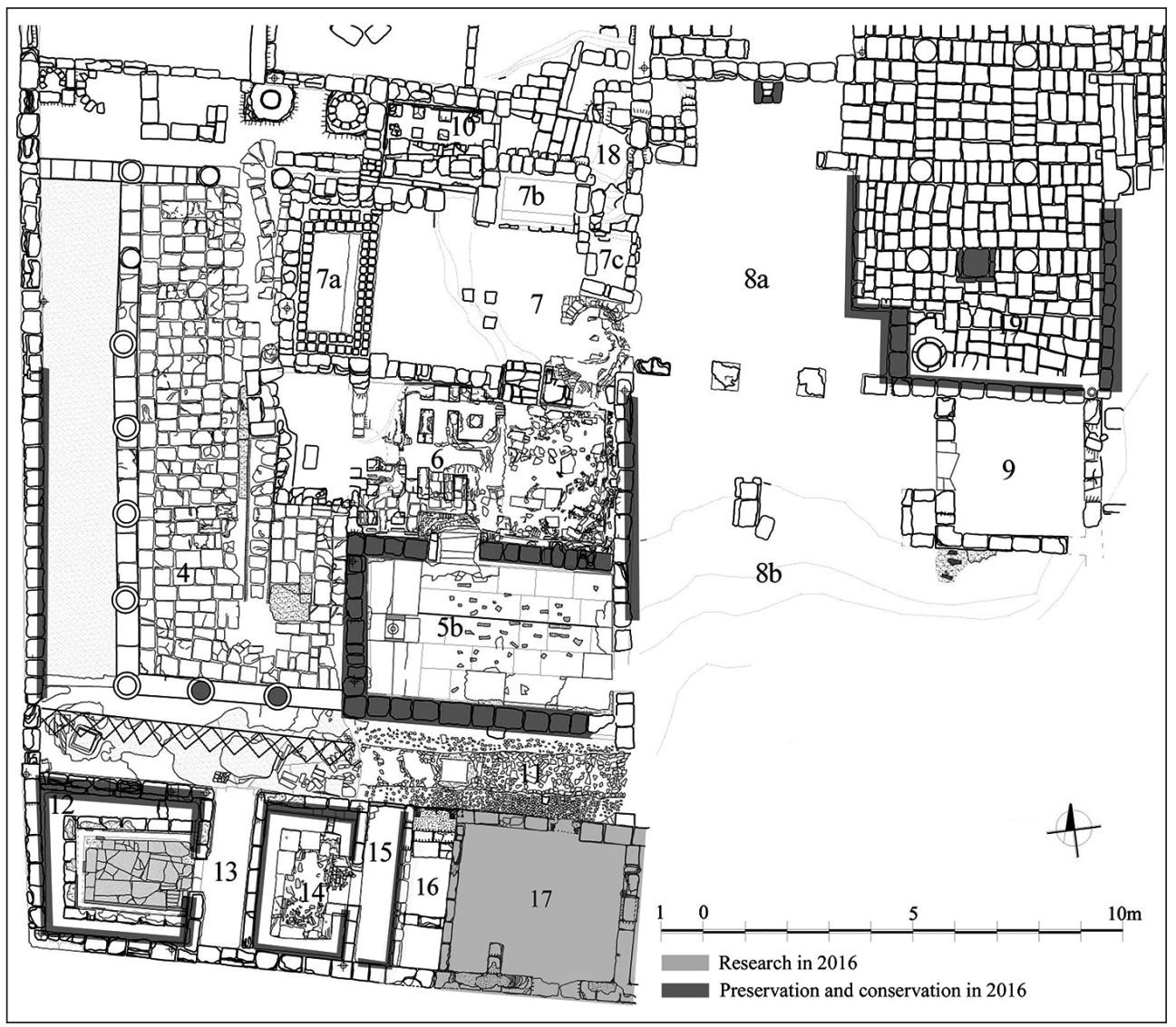

Fig. 3. Baths located south of the centralsquare at Marina el-Alamein; plan showing areas of activities in 2016 (PCMA Marina el-Alamein Conservation Mission/drawing A. Brzozowska, R. Czerner, M. Grzegorek, A. Kubicka, M. Krawczyk-Szczerbinska, K. Majdzik) 
research works in the complex since 2007 (Medeksza et al. 2010: 88-91; 2011: 116118; 2012: 84-99; Czerner et al. 2015: 113-137; 2016a: 150-161). Studies have confirmed the function of the main rooms and the existence of at least two phases of use. In the current season, research was undertaken in room 17 , a presumed apodyterium, situated in the southern part of the baths to the east of the latrines that were excavated earlier [Fig. 3]. Walls of the southeastern corner of the room and a fragment of an inner wall diverging from the south wall to the north at a distance of $0.90 \mathrm{~m}$ from the western corner were uncovered (see below). The inner wall was probably a base for a landing of the stairs, the first flight of which was situated in neighboring room 16. So far, no relics of the floor have been found. The outer south wall of the bath continues further east of room 17.

[RC]

\section{ARCHAEOLOGICAL RESEARCH}

Earlier and now continued exploration of room 17 (for previous work, see Czerner et al. 2016a: 155-156) uncovered the tops of walls: north (3.84 m long) and west $(3.49 \mathrm{~m})$, as well as south $(3.85 \mathrm{~m})$ and east $(3.26 \mathrm{~m})$. The southeastern part of the room had been damaged rather seriously, probably during building works in the 1980s that led to the discovery of the site. To the north a door opening, $0.70 \mathrm{~m}$ wide, opened into a corridor (room 11). The threshold was not apparent, but there was evidence of damage at its level. A low wall, $0.70 \mathrm{~m}$ long and $0.28 \mathrm{~m}$ wide, perhaps connected with the construction of the stairs, diverges perpendicularly from the south wall of the chamber at a distance of $0.90 \mathrm{~m}$ from its west wall. This part of the room, separated by a low wall (and probably originally situated under the stairs), differs from the eastern part. A small hearth $(0.60 \mathrm{~m}$ by $0.30 \mathrm{~m})$, surrounded by stones and brick, was located by the north wall. Fragments of ceramics, glass, animal bones (cattle, birds, fish) ${ }^{2}$ and land snails were found in the hearth. About $0.10 \mathrm{~m}$ lower in the western part of the chamber, a layer of dark soil about $0.15-0.20 \mathrm{~m}$ thick was found to contain pottery: sherds of Cypriot Sigillata bowls and jugs, dated mainly to the 2 nd century AD. ${ }^{3}$ An amphora fragment with preserved dry garum remains was also found there. There were also fragments of glass vessels (the assemblage is dated to the 1st-2nd century AD; R. Kucharczyk, personal communication), pieces of windowpanes, fragments of lamps, bronze items (two corroded rings, a netting needle, nails) and animal bones (cattle, sheep/goat, some with traces of filleting, pig and lots of fish bones). Fragments of marble tiles and pieces of painted plaster (brown and black) were discovered. A terracotta right man's foot in a sandal was also found [Fig. 4 top left]. It could be a fragment of a figurine, a votive foot or a lamp. In the same layer there was a polychromed woman's head of the "Tanagra type", made of lime mortar (traces of black color are preserved on the hair and pink on the face and neck) [Fig. 4 top right]. It has a "melon" hairstyle, a coiffure popular with Hellenistic queens (worn among others by Cleopatra VII) (Tyldesley 2008: 60-61) and upper-class

\footnotetext{
We would like to thank Dr. Urszula Iwaszczuk (PCMA UW) for the faunal identification of the bone remains. Dr. Grzegorz Majcherek (PCMA UW) kindly examined the pottery finds.
} 
women. Tanagra figurines, among others those found in Alexandria, had this kind of coiffure (Kassab Tezgör 2008: Nos 30-32, 202). Heads are decorated with a diadem or a braid, like in the case of the statuette from Marina or a Roman marble female portrait from the Louvre Museum, dated to the last quarter of the 1st century BC (Inv. Ma 3452).

In the eastern part of the room, several stone blocks lay on packed sand. By the east wall traces of small hearths have survived. In the southwestern corner, level with the preserved wall tops, part of a marble sculpture was found in a firmly packed rubble pile. It was a fragment of a right foot broken into three pieces [Fig. 4 bottom], set on a plinth. Only its anterior portion without the ankle is preserved $(12.3 \mathrm{~cm}$ long, $5.7 \mathrm{~cm}$ high and $8.1 \mathrm{~cm}$ wide). The foot is slender, presumably female, and is neatly carved. The second toe is longer than the big toe. The total length of the foot is estimated

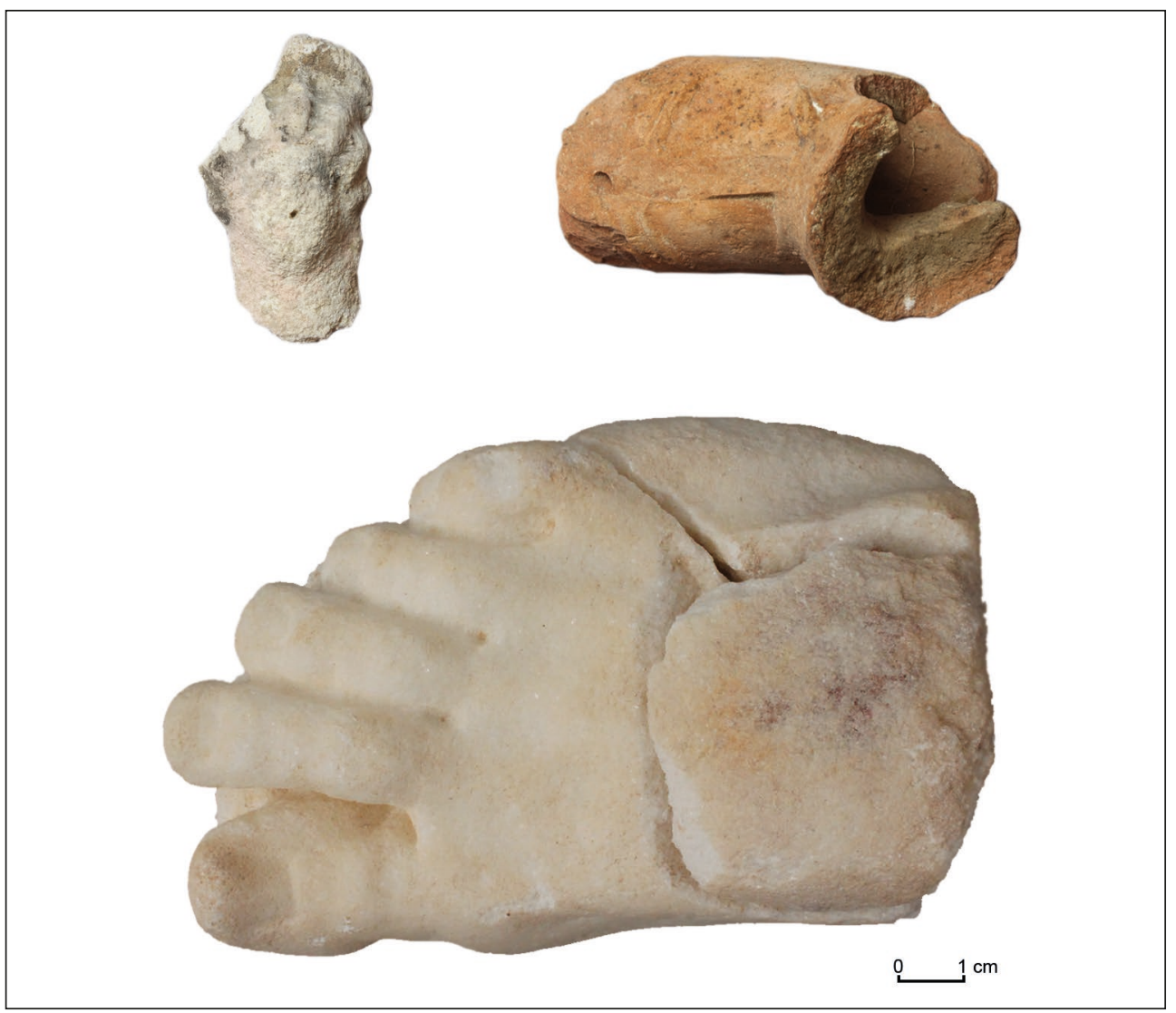

Fig. 4. Finds from room 17 of the Southern Baths: top left, a man's sandalled foot in terracotta; top right, fragmentary statuette of mortar representing a female head; bottom, fragment of a foot from a marble statuette (PCMA Marina el-Alamein Conservation Mission/photos R. Czerner) 
at about $0.22 \mathrm{~m}$. The statue to which it belongs must have been almost lifesize. A small oval hole and remains of an iron dowel inside the foot are visible, indicating that two parts of the foot may have once been connected or that the sculpture had undergone repairs in antiquity (on sculpting techniques, see more: Grossman 2003: 59). Not much can be said based on just this fragment, but naked or seminaked, and hence barefoot representations commonly depicted Aphro-dite either entering or leaving the sea.

A column drum and part of a marble hand (two fingers survive) from a different sculpture were discovered in the sand, in the southeastern part of the room. These are not the only fragments of marble sculptures found in the baths. In 2011, two pieces of a marble hand were discovered in room 8 (Czerner et al. 2014: 73).

The remains found can be tentatively dated to the 1 st through $3 \mathrm{rd}$, mainly the1st-2nd centuries AD. The research confirms the assumption from previous seasons that the baths were destroyed by the middle of the 3 rd century AD.

Preliminary examination of animal bones found in the hearths, conducted by Urszula Iwaszczuk from the Polish Centre of Mediterranean Archaeology University of Warsaw, provided information about the diet of the ancient town inhabitants. As is the case of coastal towns, many fish were eaten. This season, remnants of garum have been discovered. However, sheep/goat and cattle bones dominate. There are also bones of pigs and birds. Chicken eggshells were also identified.

\section{SURFACE FINDS}

An architectural element discovered in a rubble heap by the entrance to the basilica probably came from this building.

Several coins were found on the surface in the vicinity of house $\mathrm{H} 1$ along with fragments of bronze nails and glass. The coins were cleaned and three were found to be partly legible. Two date from the 4th century AD. One is a coin of Constantine I (AD 317-320). Its reverse shows a standing figure of Jupiter. The other depicts Constantine II as Caesar (AD 335-337). Depicted on the reverse are two soldiers with spears and shields, a military standard between them, Gloria Exercitus. The third coin comes from the 1 st or 2nd century AD. ${ }^{4}$

[GB-C]

\section{CONSERVATION}

Due to increased weathering of stone blocks in the walls, mortar joints and plaster, caused by damaging atmospheric factors in the autumn/winter period, extensive protection and conservation work was carried out inside the baths. In rooms $4,5,6,8 \mathrm{a}, 9,11-16$ and 19 , joints in the walls and their tops were filled in [for the extent of the work, see Fig. 3]. Protective mortar bands ( 6 parts sand, 3 parts lime, 1 part white cement) were applied to the edges of original plaster remains in many places within the structure. Anastylosis of two columns in the southern portico of the peristyle was supplemented with, respectively, two and three original stone drums added on top.

4 Prof. Barbara Lichocka from the Institute of Mediterranean and Oriental Cultures of the Polish Academy of Sciences kindly identified the coins. 


\section{EASTERN PERISTYLE OF THE MAIN SQUARE}

The main square of the ancient town, identified as a forum lined with porticos on the north, south and east, was excavated by Wiktor Andrzej Daszewski from the Polish Centre of Mediterranean Archaeology University of Warsaw in 2001-2005 (Daszewski 2002: 80-86; 2003: 59-65; Daszewski et al. 2005: 86-89; 2007: 76-77; Daszewski 2011: 423-429). In addition, a smaller peristyle, adjoining the square from the east, was discovered in 2002 (Daszewski 2003: 59-61) [Fig. 5]. Like the main square, it is paved with stone slabs. Stylobates on the northern, western and partly on the southern side, as well as the lower parts of the northern and western walls, have survived. On the northern and western stylobates column bases have survived in situ. Research in 2002 failed to uncover the eastern side of the peristyle. However, elements of architectural decoration of

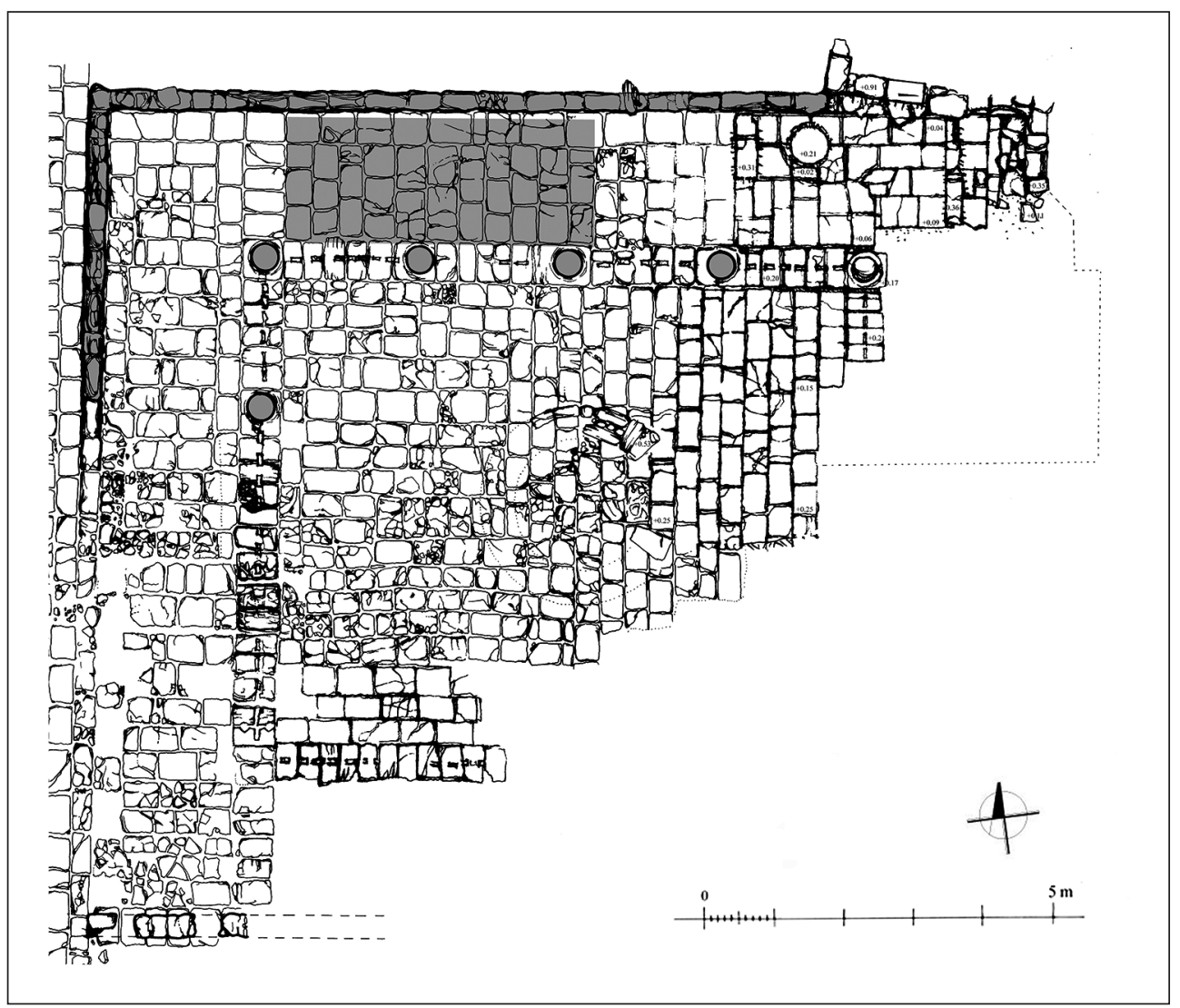

Fig. 5. Eastern peristyle of the forum; plan showing areas of conservation activities in 2016 (PCMA Marina el-Alamein Conservation Mission/drawing A. Btaszczyk, R. Czerner) 
significant size have been found in this area: a fragment of a pilaster plinth, elements of a triglyph-metope frieze and fragments of a cornice, including also an element originating from the top of a pediment (Czerner 2012: 114-117, Figs 3-6). These, considered within the context of their particular location, indicate the potential existence of an outstanding building in this place. Current research in this area uncovered the northeastern corner of the peristyle and a corner column on this side. A short fragment of the eastern stylobate was also uncovered. Densely spaced rectangular holes were discovered in all of the stylobates. These were used to insert vertical planks, which fenced off the central peristyle space. The lower part of a pseudo-Corinthian capital of a form typical of Marina and exceptionally large size, $0.50 \mathrm{~m}$ of the base diameter, was also found [Fig. 6]. Unfortunately, research in the central area east of the peristyle, where the building should have stood, revealed nothing but an extensive negative of a structure that had been pulled down.

[RC]

\section{ARCHAEOLOGICAL RESEARCH}

Conservation work in the northern part of the peristyle was preceded by the archaeological cleaning of the part of the northern portico east of the fourth column, which had failed to be examined earlier (Daszewski 2003: 59-60). Two functional layers were noted in the trench section. The earlier one was $0.10-0.05 \mathrm{~m}$ above the slabbing, the later about $0.20 \mathrm{~m}$. Two hearths were situated in the upper layer, between two low walls standing on the slabbing. The west wall $(0.30 \mathrm{~m}$ high, $0.95 \mathrm{~m}$ long) was located at a dis- tance of $4.18 \mathrm{~m}$ from the east wall of the portico.

The hearth $(0.40 \mathrm{~m}$ by $0.90 \mathrm{~m})$ discovered in its vicinity was surrounded with stones; the lower part of a pseudoCorinthian capital (see above) lay stuck in the slabbing to the east of the hearth [see Fig. 6]. The fill of the hearth yielded fragments of ceramics and animal bones, pieces of bronze and iron nails. The faunal assemblage was identified by Urszula Iwaszczuk (PCMA UW) as representing sheep/goat, cattle, fish and birds.

Another bigger hearth was located between the east wall of the portico and a low wall ( $0.53 \mathrm{~m}$ high, $1.50 \mathrm{~m}$ long) built on the slabbing at a distance of $1.15 \mathrm{~m}$ from the east wall of the portico. A large number of animal bones (pig and cattle) and fragments of ceramics were found in burnt soil, along with several pieces of

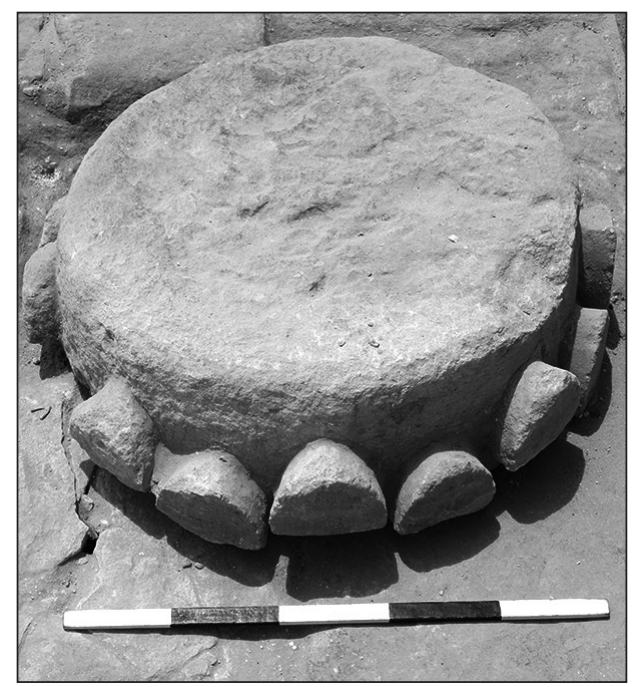

Fig. 6. Part of a pseudo-Corinthian capital from the eastern peristyle of the forum (PCMA Marina el-Alamein Conservation Mission/photo R. Czerner) 


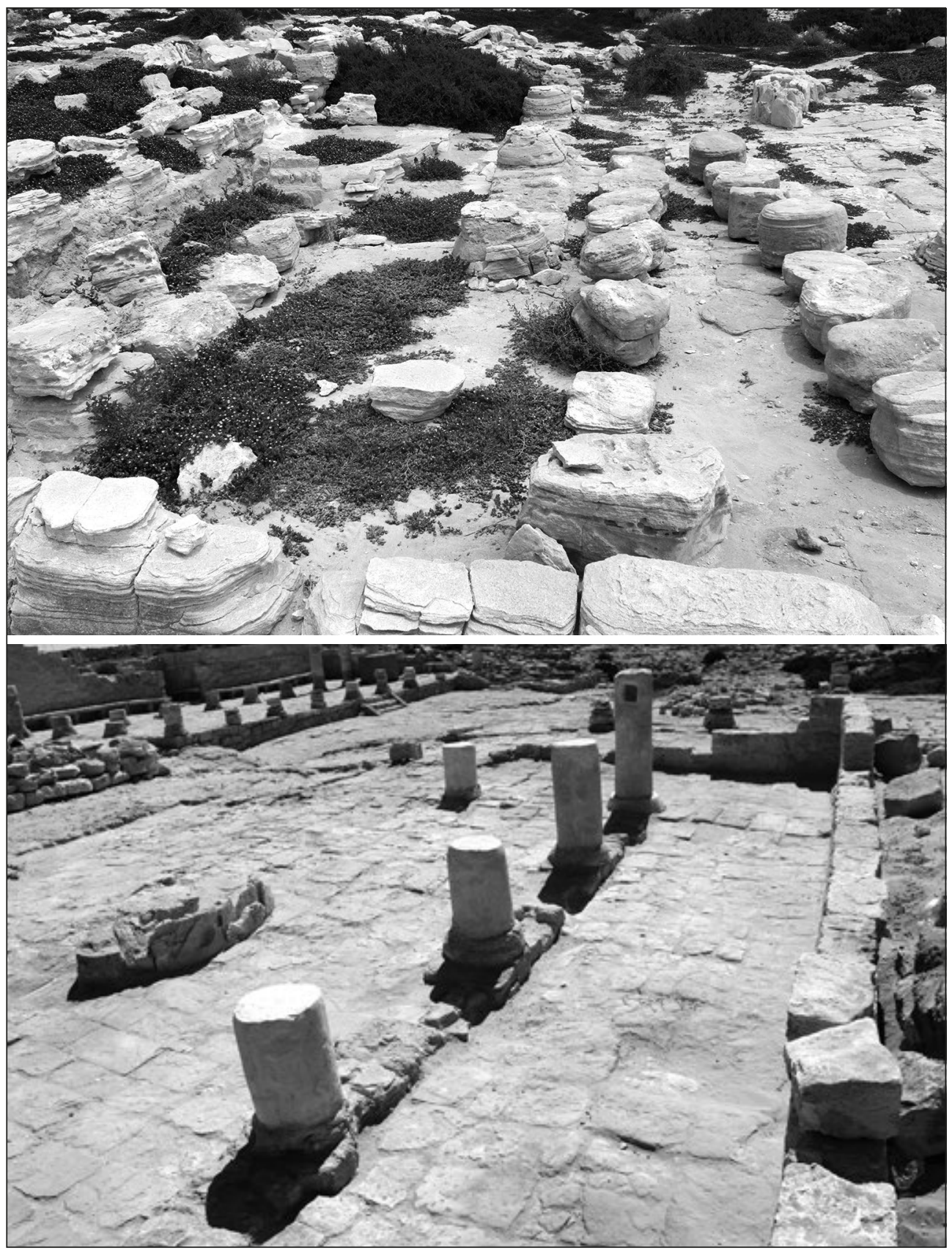

Fig. 7. Eastern peristyle of the forum: top, before and bottom, after restoration in 2016 (PCMA Marina el-Alamein Conservation Mission/photos R. Czerner) 
plaster painted black. The column bases of the southern portico of the forum appear to have been painted black as well (Daszewski et al. 2005: 86).

Fragments of ceramics, glass, animal bones, and two damaged bone pins were found during the cleaning of the pavement. The ceramics and fragments of glassware are dated to the 2 nd-3rd century AD. Hearths from a later period also yielded fragments of ceramics dated to the 4th century AD.

The eastern section of the northern stylobate was also uncovered (with one more base found in situ) as well as the badly damaged eastern stylobate. Assumptions as to the existence of pure sand behind the last base, made on the basis of the trench section, were confirmed.

The peristyle was probably built at the beginning of the 2nd century AD. The research so far may suggest that the town was partly destroyed in the middle of the 3rd century $\mathrm{AD}$ and then again in the middle of the 4th century AD. In 251, an earthquake occurred in Crete and in 262 another one in Cyrenaica; either one of these could have resulted in damage to the ancient city at the site of today's Marina el-Alamein. Next was a huge earthquake with a flood wave in 365 , during which, among others, Alexandria was destroyed. The said pseudo-Corinthian capital probably fell during the first earthquake. The low walls were erected then on the pavement and small hearths were arranged between them. After the earthquake in $\mathrm{AD} 365$, big hearths were made, used perhaps by nomads. A similar situation was recorded in the southern portico of the forum (Daszewski et al. 2005: 86).

[GB-C]

\section{CONSERVATION}

The peristyle area was particularly affected by weather conditions [Fig. 7 top]. To protect the relics, but also to provide appropriate exposition, the preserved north and west walls were also restored along with partial anastylosis of five columns and protection work on them. The most weathered blocks from the walls were replaced, 1-3 layers were added to the wall tops using original blocks from the site. The maximum height of the wall after restoration is $0.76 \mathrm{~m}$ (four courses) at the western corner. The wall undulates due to uneven ground subsidence.

Column drums were eroded and some had large losses, but their condition was satisfactory for conservation work to be carried out. To protect them, they were replaced in position on bases surviving in situ, after which they were plastered. The height of the columns after anastylosis is, in the northern row, counting from west to east: $1.52 \mathrm{~m}$ (six drums), $1.06 \mathrm{~m}$ (four drums), $0.77 \mathrm{~m}$ (three drums), $0.57 \mathrm{~m}$ (two drums), $0.23 \mathrm{~m}$ (only the base); the column in the west portico is $0.47 \mathrm{~m}$ (two drums). Lime-and-white cement mortar was used. Restoration of the eastern peristyle has enhanced the attractiveness of the area [Fig. 7 bottom].

[RC, WG] 


\section{MAIN SQUARE (FORUM)}

\section{MAINTENANCE \\ CONSERVATION}

In the area of the main square, where the mission has worked since 2006, extensive maintenance conservation was carried out during the current season [Fig. 8]. The south wall of the square and the wall on the eastern side had eroded significantly due to autumn/winter rains and winds. On the top of the south wall and in the exedra,

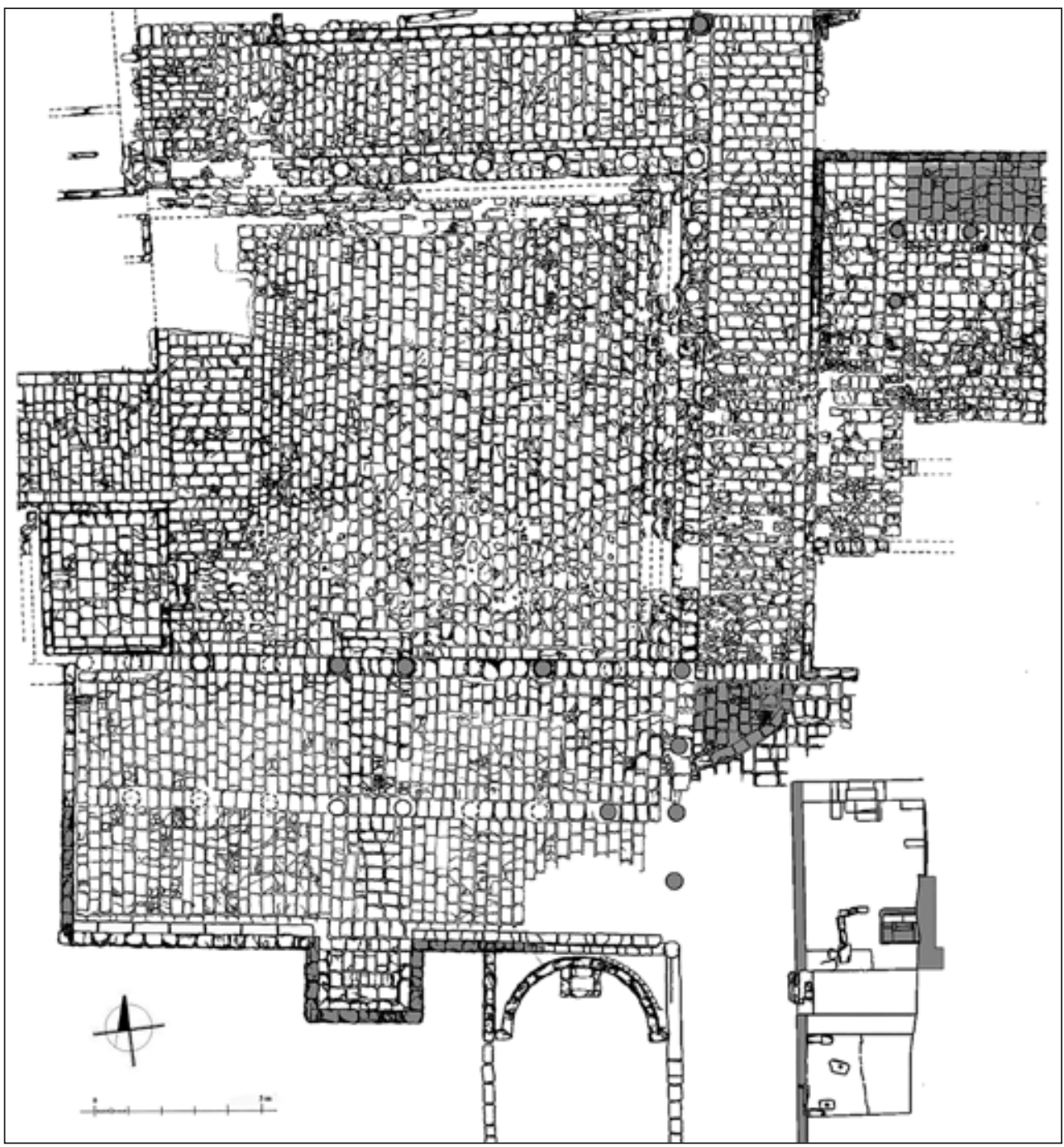

Fig. 8. Plan of the forum showing areas of conservation activities in 2016

(PCMA Marina el-Alamein Conservation Mission/drawing A. Btaszczyk, R. Czerner) 


\section{EGYPT}

situated in the middle of it, gaps appeared between blocks as a result of the joints having been worn away. Joints in the wall on the eastern side were totally degraded in many places, putting the upper sections in danger of collapse.

Maintenance conservation recreated the missing joints and the wall tops were formed in such a way as to prevent water from penetrating inside. The lower part of the east wall was treated to a height of $1.20 \mathrm{~m}$ and its upper section about $1.00 \mathrm{~m}$ from the top on both sides. Protective mortar bands were put on the edges of plaster in the exedra. Mineral mortar (6 parts sand, 3 parts lime, 1 part white cement) was used for all the work. One layer of stone blocks was added to the top of the western wall of the southern portico in order to protect it, while on the northern side of the square the anastylosis of a preserved column, started in 2015 , was continued by adding another three drums on it (up to a height of eight drums, that is, $2.15 \mathrm{~m})$.

\section{SOUTHEASTERN CORNER OF THE FORUM}

The southern portico of the forum, excavated by Daszewski between 2001 and 2004 (Daszewski 2002: 81-85; 2003: 59; Daszewski et al. 2005: 86-89; Daszewski 2011: 425), is a separate building distinctive for its layout with

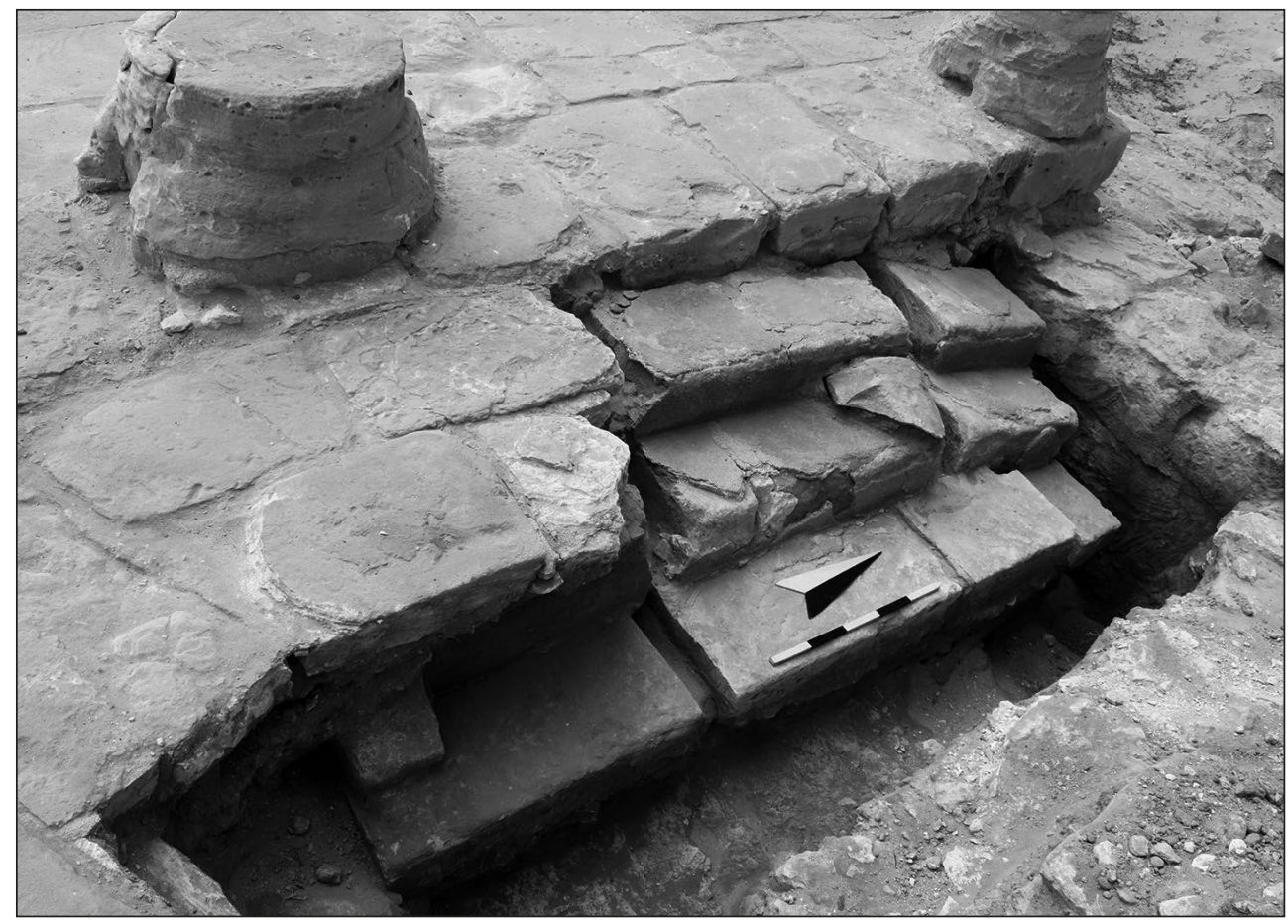

Fig. 9. Steps from an earlier phase leading to the northern aisle of the southern portico in the main square (PCMA Marina el-Alamein Conservation Mission/photo R. Czerner) 
two aisles and an exedra on the axis of the long south wall, accessed by one set of steps from the north located opposite the exedra in the central intercolumniation [see Fig. 8]. The exploration carried out in the current season on its eastern edge (the goal being to restore the slabbing at the junction of two streets) uncovered stairs from an earlier phase leading to its northern aisle, and an earlier lower level of a street paved with rubble and mortar (see below) [Fig. 9]. Covered with waterproof mortar, three steps at the southern edge were bordered with a low wall that sloped obliquely. From the north they are broken, indicating that they had originally reached the corner of the building. In this area the land sank and sloped to the north for geological reasons, and the consequences of this process had to be fixed repeatedly, which may have also entailed construction of the stairs. However, the stairs may have well come from the original phase. Then the portico would have been entered by the steps in the center from the north and by these steps from the east. But the latter also sloped to the north. More advanced repairs were undertaken then. Another layer was added on the floor of the northeastern corner of the building which had also sunk. A new pavement of limestone slabs was laid on the street on a higher level. There the southern part of the pavement was supported from the north by a curved retaining wall hidden under it. Starting from this wall, the northern part of the pavement slopes quite steeply to the north as far as the newly constructed wall running east in the extension of the stylobate. This part of the newly laid pavement covered the said steps. The changes discussed above document part of a more extensive alteration of the building (the two-aisled portico), since levelling of the descending floor entailed the construction of at least six new columns on it.

\section{CONSERVATION}

After documenting the excavated steps, the damaged flooring was reconstructed following the original scheme. The lower parts of some columns in the two-aisled southern portico were restored by filling in the joints between the drums.

$[\mathrm{RC}]$

\section{ARCHAEOLOGICAL RESEARCH}

While repairing the slabbing in the northern portico, the peristyle, and the eastern portico in the forum, three test trenches were dug. The fill yielded small fragments of ceramics, mostly nondiagnostic. Steps from an earlier phase were uncovered in the probe in the southeastern corner of the forum, under the slabbing east of the double portico, by its eastern stylobate. There were three steps ( $2.00 \mathrm{~m}$ long, each $0.14 \mathrm{~m}$ high), all damaged and slipping to the north. Waterproof plaster has survived on them in some places. A bedding layer for the slabbing (about $0.10 \mathrm{~m}$ ) was noted, another one about $0.25 \mathrm{~m}$ below the slabbing. Traces of a street surface were observed at a depth of about $0.42-0.45 \mathrm{~m}$. Glass and pottery sherds were found in the fill, along with small pieces of plaster. On the second step, there was a fragment of a column drum. The pottery will continue to be studied in the coming season, but it is already clear from this investigation that the redevelopment of this part of the forum took place in the beginning of the 2 nd century $\mathrm{AD}$.

[GB-C] 


\section{MAINTENANCE CONSERVATION AND PROTECTION IN THE AREA OF THE RESIDENTIAL BUILDINGS}

\section{CONCLUSIONS AND \\ CONSERVATION OBJECTIVES}

An important task of the Mission is to monitor continuously processes taking place in wall structure and on the surface of elements of architectural decoration in relation to the conditions of exposure. Data collected from the excavation and conservation work contribute to a fuller recognition of ancient technologies and durability of the structure.

Indeed, excavations have revealed ample evidence of conservation measures undertaken in antiquity. It was common practice in ancient times to use stone blocks of varying quality (mainly due to reuse of building material). Moreover, the limestone used for building in Marina is characterized by poor resistance to the damaging effects of weather conditions. Location is the key factor in this respect. The north and south faces of walls appear most prone to weathering, being affected by the sea (from the north) and desert insolation (from the south). These phenomena are escalated near the shore, where high air humidity is accompanied by salinity of the building material. This results in the destruction of weakened blocks and joints. Stone surfaces are exposed many times a year to desert storms of hurricane proportions and heavy rains during autumn and winter, such as the unprecedented in recent times downpour at the turn of 2015. It resulted in washouts appearing in building foundations throughout the ancient town. Rubble masonry walls were most severely affected (in houses $\mathrm{H} 9, \mathrm{H} 9 \mathrm{a}, \mathrm{H} 10)$. Breaches up to $2 \mathrm{~m}^{2}$ in size were formed at the wall bases, while the conserved wall tops from 1988-1990 survived in a relatively good condition, confirming once again the appropriateness of the technology adopted in the course of this mission's conservation work. Reacting to the new damages, conservators replaced the joints in the lowermost parts of the walls using lime-cement mortar in lieu of the original clay and sand. Walls in these areas were dismantled and rebuilt.

Historical construction techniques are also at fault when considering damage of the lowermost parts of walls. Stone walls were bonded with clay and sand, and the joints were protected with lime-based plaster, which is not particularly effective, considering that the walls are subject to the action of rainfall water running downhill. Natural culverts of unstable ground were formed in places of seasonal currents. Improving the local drainage system by directing the water flow so as to minimize the loss of historical substance can prevent such adverse effect from taking place. Activities of this kind are implemented parallel with repairing wall damage and relaying of the masonry as required.

The following conclusions can be formulated folowing an analysis of the current state of preservation of the ancient architectural relics in Marina el-Alamein:

1. The limestone material, used for the walls and elements of architectural decoration in the ancient town, is diversified in terms of technical parameters. Block erosion was observed in varying degrees, independently of the location. Different quarry sources 


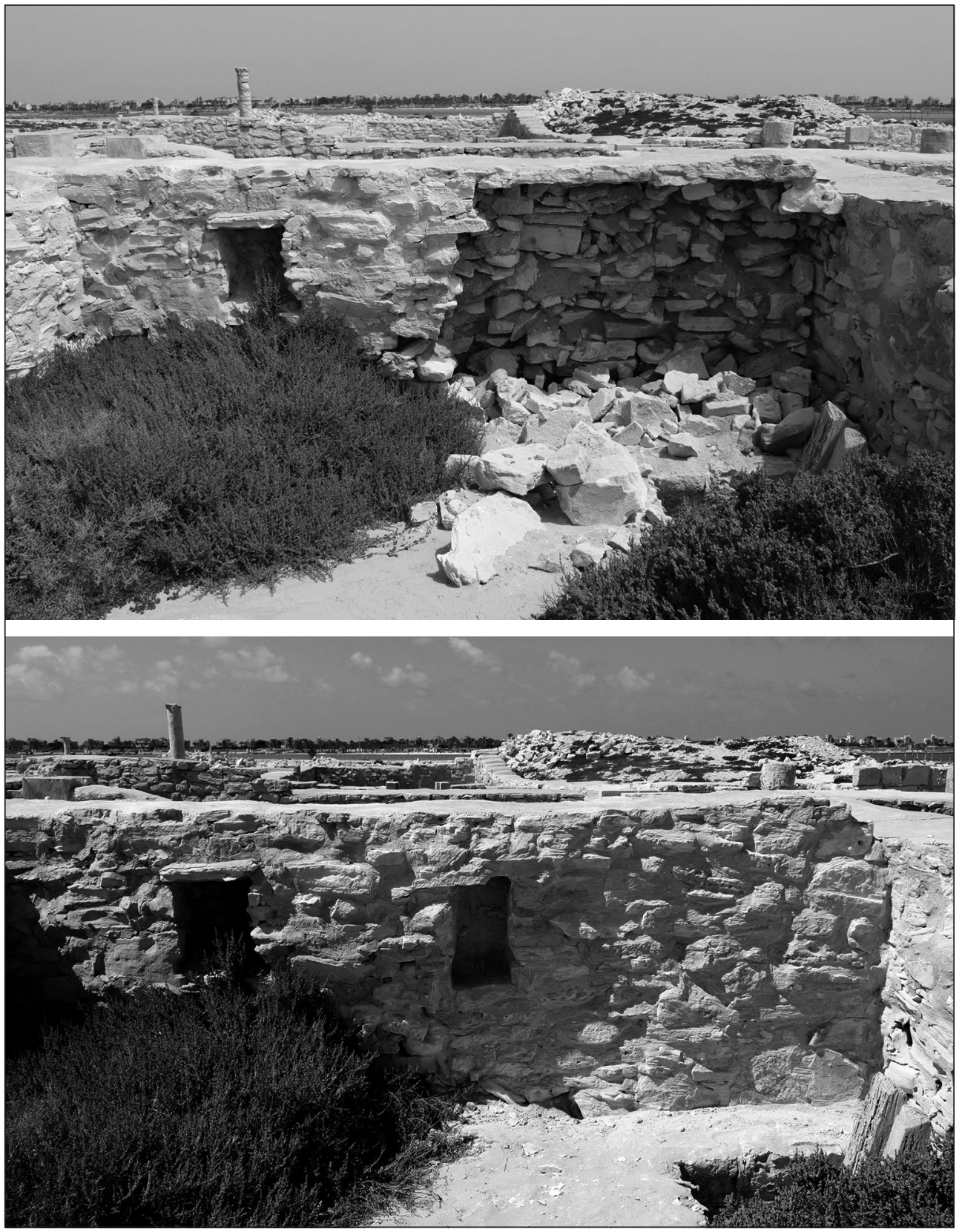

Fig. 10. Conservation maintenance in House H9: top, a wall in collapsed condition after the winter rains; bottom, after reconstruction in 2016 (PCMA Marina el-Alamein Conservation Mission/photos R. Czerner) 


\section{EGYPT}

from which the stone material issued in antiquity played a role in this. Evidence of repairs of such damage to building stones already during the functioning of the town has been noted.

2. Present conservation assumes maximum use of original stone blocks, locally complemented with new material. Reconstructions made of building stone quarried today mostly concern elements of architectural decoration (column drums and carved architectural decoration).

3. Structural damage to the walls results mostly from water runoff in the autumn and winter. This phenomenon is especially intense in the zone of houses in the central part of the town.

4. Damage to particular stone blocks in walls can be seen throughout the town and is not uniform in nature, as it presents varying degrees of deterioration. The most common phenomenon is the loss of cohesion of the subsurface and powdering of surfaces.

5. Damage to the joints between the blocks is particularly pronounced on the east-west axis and is associated with the direction of the prevailing winds (desert storms).

6. Substantial damage to the walls can be seen in the part of the town closest to the sea. This mostly concerns houses $\mathrm{H} 21, \mathrm{H} 1, \mathrm{H} 2$, where wind erosion is intensified by ground salinity.

7. The greatest damage to blocks occurs in the south and southwest, which is associated with exposure to sunlight and water migration accompanied by crystallization of salts in the stone.

8. Remains of the necropolis in the southern part of the town are relatively in the best condition. Their location, on a hill lying about $200 \mathrm{~m}$ south of the sea shore, essentially improves the state of preservation of the walls and decoration.

\section{AREAS OF CONSERVATION}

Extensive maintenance conservation work was carried out again in the area of residential buildings. This year, however, the activities had a broader scope.

\section{House H9 (rubble masonry walls)}

Heavy rainfall in the winter of 2015/2016 resulted in a partial inundation of the area of the ancient town, fostering plant growth in the ruins in effect. Rainwater flowing from the direction of the modern asphalt road wore away the mortar from house wall joints, causing the collapse of large sections of walls in several places, except for upper parts that had previously been consolidated with mortar [Fig. 10

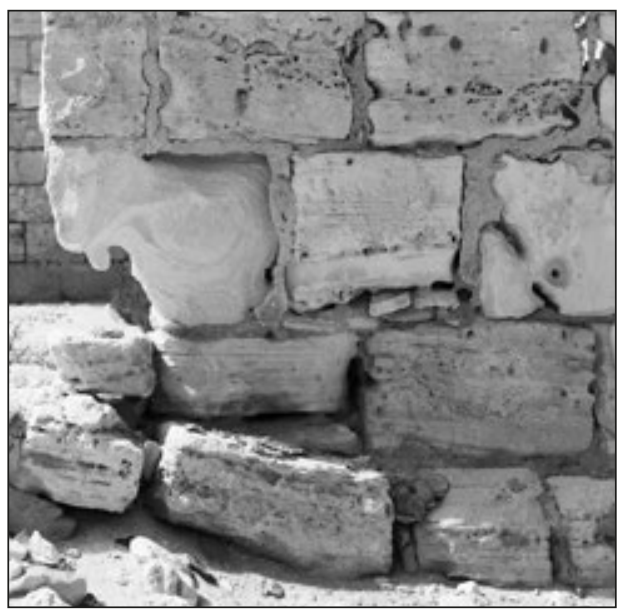

Fig. 11. House H21N: losses of stone blocks in the wall next to the passages (PCMA Marina el-Alamein Conservation Mission/photo P. Zambrzycki) 
top]. The walls in question, about 0.50 $0.75 \mathrm{~m}$ thick, were built of crushed rock rubble and bonded externally with lime mortar and internally with clay mortar. Repairwork involved using crushed rock rubble and mineral mortar ( 6 parts sand, 3 parts lime, 1 part white cement) [Fig. 10 bottom]. The following areas of house $\mathrm{H} 9$ were thus treated: south wall of room 9 , north wall of room 10 (a recess was reconstructed in it), south and west walls of the tavern.

In houses $\mathrm{H} 9 \mathrm{a}$ and $\mathrm{H} 10 \mathrm{a}$, the two most weathered columns were protected. Losses in plaster and mortar in the joints between the drums of shafts were filled in.

[WG]

\section{House H21N}

The house had undergone conservation treatment last time in 2007, when an anastylosis of the commemorative monument to Commodus was carried out in the southern part of the house (Medeksza et al. 2010: 88; Czerner and Medeksza 2010: 109-112). Assessment of the state of preservation of the historic substance in 2016 led to identification of zones of damage that comprised the walls of the entrance from the north to the hall with aedicule, and the wall with the aedicule. The damage was one of two kinds:

- joint loss (in some places reaching through to the other side of the wall);

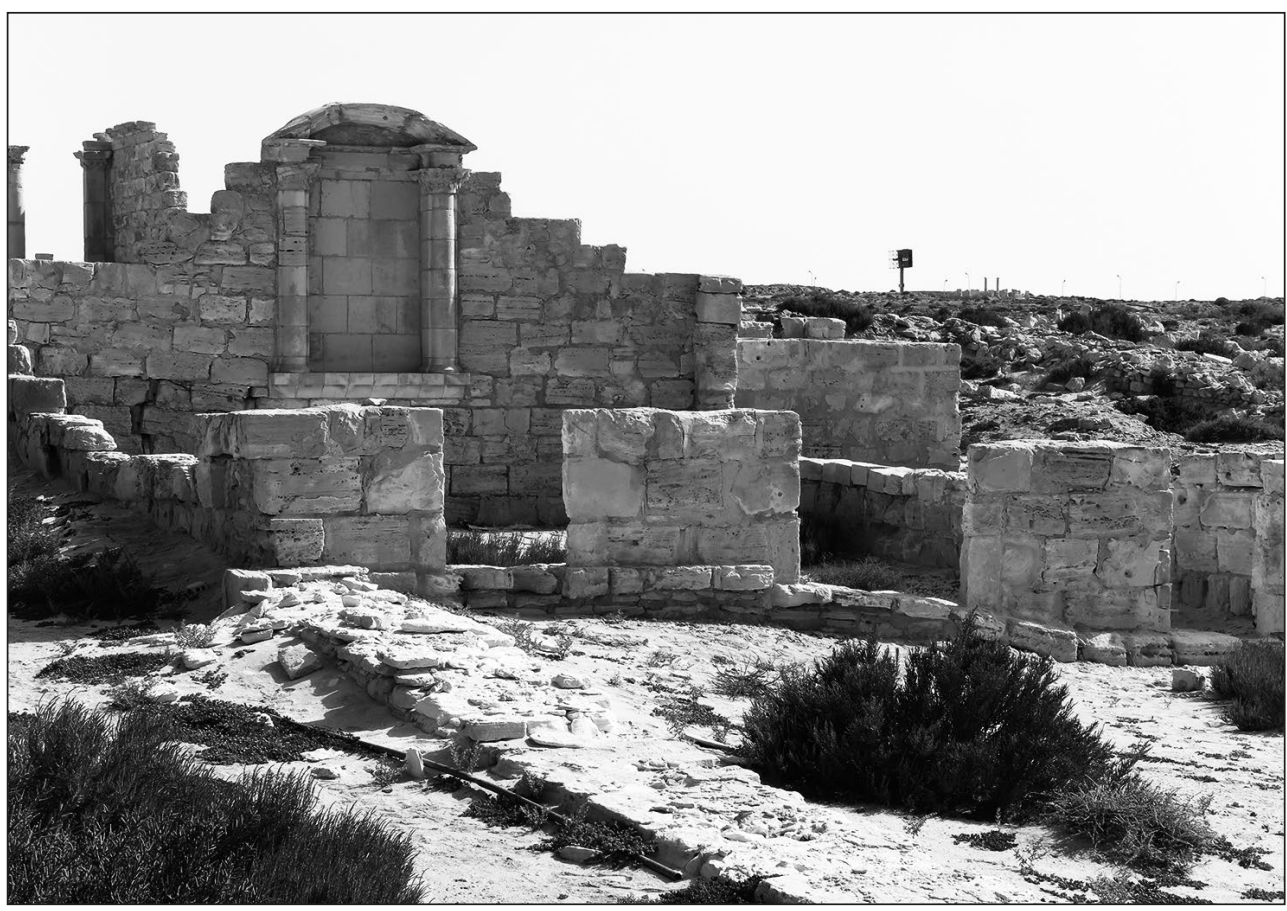

Fig. 12. House H21N after the conservation of walls in 2016 (PCMA Marina el-Alamein Conservation Mission/photo P. Zambrzycki) 
- loss of stone blocks (degradation increased around the house entrances). The most damaged blocks were located in the passages and on the southern side of the walls [Fig. 11].

Standard preventive conservation mea-sures were undertaken. The losses in wall joints were filled in with mineral mortar (6 parts sand, 3 parts lime, 1 part white cement). Around the entrance openings damaged parts of blocks were removed and replaced with original ancient stones collected at the site. The joints were filled with mortar [Fig. 12].

\section{CONSERVATION OF BRONZE ARTIFACTS}

Bronze coins and nails are among the artifacts commonly recovered from the cleaning preceding conservation around the ancient houses. Basic conservation procedures are carried out in the mission's field lab, designed to stop the degradation processes and to restore the original condition to the largest extent possible.

Conservation treatment was preceded by photographic documentation. First the green sulphate deposits were removed with an aqueous solution of sulphuric acid. The objects were then cleaned in an ultrasonic cleaner using water as solvent. The cuprite shell of brown-red color was revealed as a result of this treatment. Cleaning was continued in the case of objects which could not be identified due to a very thick layer of corrosion. For this purpose the objects were soaked in an aqueous solution of disodium edetate and cleaning was performed in an ultrasonic washer. Then the objects were rinsed in water. Locally occurring thick deposits of cuprite were removed mechanically using glass fiber sticks. The cleaned metal surface was protected with a solution of PARALOID B-72 in toluene and photographic documentation was made.

\section{Prof. Rafał Czerner}

Wrocław University of Science and Technology, Faculty of Architecture

50-317 Wrocław, Poland, ul. Bolesława Prusa 53/55

rafal.czerner@pwr.edu.pl

Dr. Grażyna Bąkowska-Czerner

Jagiellonian University in Kraków, Center for Comparative Studies of Civilizations

31-044 Kraków, Poland, ul. Grodzka 52

grazyna.bakowska-czerner@uj.edu.pl

Wiesław Grzegorek

wieslawgrzegorek@wp.pl

Piotr Zambrzycki

InterAcademy Institute of Conservation and Restoration of Works of Art

00-379 Warsaw, Poland, ul. Wybrzeże Kościuszkowskie 37

mik@asp.waw.pl 


\section{REFERENCES}

Breccia, E. (1923). Di alcuni bagni nei dintorni d'Alessandria. Bulletin de la Société Archéologique d'Alexandrie, 19, 142-151

Czerner, R. (2012). Ricostruzione teorica degli edifici monumentali di Marina el-Alamein. Aegyptus, 89, 111-123

Czerner, R., Bąkowska-Czerner, G. with contributions by W. Grzegorek and A. Jasiewicz. (2014). Marina el-Alamein Polish-Egyptian Conservation Mission: research and conservation in the 2011 season. PAM, 23/1, 63-77

Czerner, R., Bąkowska-Czerner, G., Grzegorek, W., and Majcherek, G. (2016a). Research and conservation in Marina el-Alamein in 2014 and 2015 (Polish-Egyptian Conservation Mission). Part one: The Southern Bath and central town square. PAM, 25, 145-166

Czerner, R., Bąkowska-Czerner, G., Grzegorek, W., and Majcherek, G. (2016b). Research and conservation in Marina el-Alamein in 2014 and 2015 (Polish-Egyptian Conservation Mission). Part two: the Hellenistic baths. PAM, 25, 167-184

Czerner, R., Bąkowska-Czerner, G., and Majcherek, G. (2015). Research and conservation in the Roman baths of Marina el-Alamein in the 2012 and 2013 seasons (Polish-Egyptian Conservation Mission). PAM, 24/1, 113-138

Czerner, R. and Medeksza, S. (2010). The Commodus monument from House H21C in Marina el-Alamein. PAM, 19, 98-113

Daszewski, W.A. (1991). Marina El Alamein - the site of an unknown Graeco-Roman settlement on the Mediterranean coast of Egypt. In W.A. Daszewski, W. Bentkowski, U. Fidecka, A. Sawecki, J. Radzik, Z. Sztetyłło, and G. Majcherek, Marina El Alamein: Archaeological background and conservation problems. The Polish-Egyptian Preservation Mission at Marina, 1988. The Polish Excavation Mission at Marina, 1987-1989, I [=Reports of the Research-Conservation Mission of PKZ 18] (pp. 7-18). Warsaw: State Enterprise, the Ateliers for Conservation of Cultural Property (PKZ)

Daszewski, W.A. (1995). Témoignage de l'urbanisation de la côte méditerranéenne de l'Égypte à l'époque hellénistique et romaine à la lumière des fouilles de Marina el-Alamein. BSFE, 132, $11-29$

Daszewski, W.A. (2002). Marina el-Alamein. Season 2001. PAM, 13, 73-86

Daszewski, W.A. (2003). Marina el-Alamein. Excavation report 2002. PAM, 14, 49-65

Daszewski, W.A. (2011). Graeco-Roman town and necropolis in Marina el-Alamein. PAM, 20, $421-456$

Daszewski, W.A. in collaboration with I. Zych, G. Bąkowska, A. Błaszczyk. (2005). Marina el-Alamein. Excavation report 2004. PAM, 16, 73-92

Daszewski, W.A. in collaboration with I. Zych, G. Bąkowska, A. Błaszczyk. (2007). Marina el-Alamein. Excavation report, 2005. PAM, 17, 75-97

Fournet, T., Lucore, S.K., Redon, B., and Trümper, M. (2013). Catalog. In S.K. Lucore and M. Trümper (eds), Greek baths and bathingculture: New discoveries and approaches $[=B A B E S C H$ Supplement 23] (pp. 269-333). Leuven-Paris-Walpole, MA: Peeters

Grossman, J.B. (2003). Looking at Greek and Roman sculpture in stone: A guide to terms, styles and techniques. Los Angeles: The J. Paul Getty museum 


\section{EGYPT}

Kassab Tezgör, D. (2007). Tanagréennes d'Alexandrie: figurines de terre cuite hellénistiques des nécropoles orientales, Musée gréco-romain d'Alexandrie [=Études alexandrines 13]. Cairo: Institut français d'archéologie orientale

Krencker, D., Krüger, E., Lehmann, H., and Wachtler, H. (1929). Die Trierer Kaiserthermen I. Ausgrabungsbericht und grundsätzliche Untersuchungen römischer Thermen [=Trierer Grabungen und Forschungen 1/1]. Augsburg: Filser

Medeksza, S. with contributions by G. Bąkowska, R. Czerner and P. Zambrzycki (2010). Marina el-Alamein. Conservation work in the 2007 season. PAM, 19, 81-97

Medeksza, S., Czerner, R. with G. Bąkowska, W. Grzegorek, R. Kucharczyk, J. Lis, and P. Zambrzycki (2011). Marina el-Alamein. Polish-Egyptian Restoration Mission: Conservation work in 2008. PAM, 20, 103-128

Medeksza, S., Czerner, R., Bąkowska-Czerner, G. with contributions by I. Fuks-Rembisz, W. Grzegorek, G. Majcherek, M. Mrozek-Wyscoka, and P. Zambrzycki (2012). Marina elAlamein. Conservation work in the 2009 season. PAM, 21, 79-105

Nielsen, I. (1990). Thermae et balnea: The architecture and cultural history of Roman public baths I. Text. Aarhus: Aarhus University Press

Trümper, M. (2009). Complex public bath buildings of the Hellenistic period. A case study in regional differences. In M.-F. Boussac, T. Fournet, and B. Redon (eds), Le bain collectif en Égyte: Balaneîa $=$ Thermae $=$ Hammâmât $[=$ Études urbaines 7] (pp. 139-179). Cairo: Institut français d'archéologie orientale

Tyldesley, J. (2008). Cleopatra: Last queen of Egypt. London: Profile Books

Yegül, F.K. (1992). Baths and bathing in classical antiquity. New York-Cambridge, MA: Architectural History Foundation; MIT Press 
